\title{
HUMAN RESOURCE MANAGEMENT AND PERFORMANCE IN THE SERVICE SECTOR: THE CASE OF BANK BRANCHES
}

\author{
Ann P. Bartel \\ Working Paper 7467 \\ http://www.nber.org/papers/w7467 \\ NATIONAL BUREAU OF ECONOMIC RESEARCH \\ 1050 Massachusetts Avenue \\ Cambridge, MA 02138 \\ January 2000
}

Funding for this paper was received from The Alfred P. Sloan Foundation via a grant to the Industrial Technology and Productivity Project of the National Bureau of Economic Research. The author gratefully acknowledges helpful comments and suggestions received from seminar participants at the Columbia Business School Finance Free Lunch and the NBER Summer Institute. Sincere thanks to Adriana Lleras-Muney for excellent research assistance on this project. The views expressed herein are those of the author and not necessarily those of the National Bureau of Economic Research.

(C) 2000 by Ann P. Bartel. All rights reserved. Short sections of text, not to exceed two paragraphs, may be quoted without explicit permission provided that full credit, including $\mathbb{C}$ notice, is given to the source. 
Human Resource Management and Performance in the

Service Sector: The Case of Bank Branches

Ann P. Bartel

NBER Working Paper No. 7467

January 2000

JEL No. J24, L8, M12

\begin{abstract}
This paper utilizes a unique dataset collected through site visits to extend the analysis of the relationship between the human resource management environment and establishment performance to the service sector, specifically the branch operations of a large bank. Case studies of several branches were used to understand how and why the human resource management environment is likely to affect branch level performance. The branch interviews were instrumental in properly specifying a branch-level performance equation. The econometric analysis showed that, controlling for the characteristics of the market in which the branch is located and the characteristics of the branch employees, as well as unobserved branch-specific and unobserved manager-specific characteristics, the human resource management environment at the branch, as measured by the performance evaluation and feedback system and the quality of communications between the manager and the staff, had a significant effect on the branch's performance. An important finding is that, even though all managers in this bank are given a formal set of human resource policies, they appear to have considerable discretion in their application.
\end{abstract}

Ann P. Bartel

Graduate School of Business

Columbia University

710 Uris Hall

New York, N.Y. 10027

and NBER

apb2@columbia.edu 


\section{Introduction}

Many managers and analysts believe that human resource management can substantially improve corporate performance. But, despite case studies and theoretical analyses of the optimal ways to organize workplaces and manage labor (Lazear, 1991, 1992; Milgrom and Roberts, 1990, 1995; Baker, Gibbons and Murphy, 1994; and Holmstrom and Milgrom, 1994, among others), there is little systematic evidence on the actual impact of these practices on performance. Empirical research on human resource management that does exist tends to focus on blue collar workers in manufacturing despite the fact that most employees work in white collar occupations and service sector industries. ${ }^{1}$ Productivity studies on the service sector are particularly rare, partly because of the problems in measuring output in this sector (Griliches, 1992).

This paper extends the analysis of the relationship between the human resource management environment and establishment performance to the service sector by examining the branch operations of a large Canadian bank. A unique dataset collected through site visits was created for this research project. Although analyzing data from one company may lead to the criticism that the findings can not be generalized to other work settings, there are two important reasons for focussing on one company in this study. First, since all the branches in this bank are producing the same products using the same production process, it is possible to estimate the impact of the human resource management environment without worrying about the confounding impact of unmeasured attributes of the firm's production process. Previous studies of productivity in the banking industry indicate the importance of

\footnotetext{
${ }^{1}$ For a review of studies on HRM and manufacturing productivity, see Ichniowski, Kochan, Levine, Olson and Strauss (1996).
} 
getting "inside the black box" (Berger and Mester, 1997), which can only be done through detailed analysis at the plant level, i.e. the branch. Second, although this study pertains to only one bank, the Canadian banking industry is dominated by five major banks, so that the analysis presented here is a good representation of the Canadian banking industry as a whole.

This paper should also be viewed as part of the emerging literature on personnel economics recently reviewed by Lazear (1999). As Lazear points out, the availability of firm-based data enables economists to explore new questions and provide answers that can help to guide business policy. The analysis presented in this paper is one example of how an economics framework can be used to study issues relating to the internal operations of a firm.

Section II reviews the previous literature on the determinants of productivity in the banking industry and shows that these studies have largely focussed on the role played by scale in determining the efficiency of a bank or a branch. None of the previous studies has considered other determinants of performance at the branch level. Section III discusses the findings obtained from several case studies of branches in the Canadian bank, and motivates how and why the human resource management environment is likely to affect branch level performance. In Section IV, a performance equation for a bank branch is specified and the data that are used for the estimation are described. Section V presents the results of estimating the equation utilizing data for the time period 1995-1997 on branches operated by the bank in metropolitan areas in the province of Ontario. The main finding in Section $\mathrm{V}$ is the significant positive impact of certain attributes of the human resource management environment on branch level performance, even in a model that controls for unobserved branch characteristics and unobserved manager characteristics. Consistent with the observations made during the branch visits, 
the empirical analysis finds significant effects of the quality of the performance evaluation and feedback system and the quality of communications between the manager and staff and between co-workers. The fact that these human resource management activities are significant in a model that includes branch and manager dummy variables implies that branch-level performance can be impacted by specific actions undertaken by the managers. Section VI concludes.

\section{Previous Literature on Productivity in the Banking Industry}

\section{A. The Bank as the Unit of Observation}

The literature on productivity in the banking industry has struggled with the question of how to define a bank's output. Berger and Humphrey (1992) describe the three alternative methods of defining bank output: the asset, user cost, and value-added approaches. Under the asset approach (also called the intermediation approach), banks are considered as financial intermediaries between liability holders and those who receive bank funds. Loans and other assets are considered to be bank outputs while deposits and other liabilities are treated as inputs.

Some examples of studies using this approach are Elyasiani and Mehdian (1990a, 1990b) who found that larger banks are more scale efficient and that the banking industry experienced technological progress during the 1980 s.

As Berger and Humphrey point out, banks do more than purchase their funds - they provide services to depositors such as the ability to write checks and the ability to withdraw cash, but these services are not counted as output in the asset or intermediation approach.

The user cost approach determines whether a financial product is an input or an output on the basis of 
its net contribution to bank revenue. Using this approach, Hancock (1986) found that loans and demand deposits tend to be net revenue earners while time deposits have a positive user cost. Hence, Hancock treated loans and demand deposits as outputs and classified time deposits as inputs along with cash, labor, materials and capital. ${ }^{2}$

The third approach, the value-added or production approach, views banks as "producing" demand deposits, time and savings deposits, commercial loans, real estate loans, and installment loans, using capital, labor and materials to do so. ${ }^{3}$ It has been argued (Ferrier and Lovell, 1990) that this approach is appropriate for studying the cost efficiency of banks since it is concerned with just the operating costs of banking, while the intermediation approach is concerned with the overall costs of banking and is appropriate for addressing questions concerning the economic viability of banks.

An example of an early study that used the production approach is Benston, Hanweck and Humphrey (1982) who used the data from the Federal Reserve's Cost Analysis (FCA) program for the time period 1975-1978 to study scale economies in banking. They estimated a translog cost function and argued that output should be measured in terms of what banks do that cause operating expenses to be incurred. Hence, the dependent variable was the sum of all operating expenses other than interest payments for the five primary bank services - demand deposits, time and savings deposits, real estate loans, installment loans, and commercial and industrial loans. Output was defined as either the number

\footnotetext{
${ }^{2}$ Aly et.al. (1990) used the same classification as Hancock and found that pure technical efficiency in the banking industry was positively related to size as measured by total deposits or number of branches.

${ }^{3}$ As Berger and Humphrey (1992) explain, much of the controversy regarding the treatment of deposits as an input or an output occurs because the explicit revenues on deposits are relatively small. Hence, in banking, it may not be appropriate to use explicit revenues to determine outputs.
} 
of deposit and loan accounts or the dollar value of deposits and loans. In a more recent study, Berger and Humphrey (1992) estimated a translog cost function for 14,000 U.S. banks for the years 1980, 1984 and 1988 and defined output as the deflated values of deposit and loan balances. They argued that these real dollar balances are proportionate to the underlying transactions and account maintenance service flows for the deposit categories and the transactions, credit evaluation, and monitoring service flows for the loan categories, and hence are similar to the outputs used in the BLS measure of bank labor productivity. ${ }^{4}$ A third example of the production approach is Prasad and Harker (1997) who used data on 47 banks from the 1994 Wharton Financial Institutions Center survey to estimate the impact of information technology on productivity in the industry. A Cobb-Douglas production function was estimated in which the dependent variable was the average annual value of loans and deposits for the bank during the time period 1993-1995.

\section{B. The Branch as the Unit of Observation}

There have been a number of analyses focussing on branch performance within a single banking firm using either parametric methods or nonparametric methods such as Data Envelopment Analysis (DEA). DEA compares each branch with all of the other branches in the observation set and identifies the relatively more efficient (best practice) subset of branches and the subset of branches that are relatively inefficient. DEA assumes that there is no random error; all variation not in the inputs is treated as reflecting inefficiency. Output is measured as the number of transactions (e.g. new accounts, closed accounts, loan applications, checks cashed, travelers checks sold) processed by the branch and inputs

\footnotetext{
${ }^{4}$ The BLS uses a set of aggregate transaction flow data on major deposit and loan services, such as the number of checks written for demand deposits, the number of savings deposits and withdrawals for time and savings accounts, and the number of new loans for real estate, commercial and installment loans.
} 
are number of employees, office space, and supplies. As Berger, Leusner and Mingo (1994) point out, many studies that use DEA use a small number of observations relative to the number of inputs and outputs $^{5}$ and are therefore predisposed to find that most branches are efficient. ${ }^{6}$ An exception is the work by Schaffnit, Rosen and Paradi (1997) who studied 291 Ontario-based branches of a large Canadian bank. Using data for 1993 , they found that $44 \%$ of the branches were technically and scale efficient and rural branches were more efficient than urban branches. ${ }^{7}$

The main findings of the studies that use parametric methods is the existence of scale economies at the branch level. This is demonstrated in the work by: (1) Murphy and Orgler (1982) who estimated a Cobb-Douglas cost function for one year (1976) on 127 branches of an anonymous bank in a small country; (2) Doukas and Switzer (1991) who estimated a translog cost function using one calendar quarter of data (10/31/85 to 1/31/86) on 563 branches of an anonymous Canadian bank, and (3) Zardkoohi and Kolari (1994) who estimated a translog cost function using 1988 data on 615 branches of 43 Finnish savings banks. The findings of scale economies is consistent with the idea that a profitmaximizing bank would have branches below cost-efficient scale in order to provide more customer convenience and earn higher revenues.

The best study of branch-level productivity is the one by Berger, Leusner and Mingo (1994) who utilized data on 760 branches in a large U.S. commercial bank for the time period 1989-1991.

\footnotetext{
${ }^{5}$ Sherman and Gold (1985) analyzed 14 branch offices and Parkan (1987) studied 35 branches.

${ }^{6}$ For a branch to be found to be $100 \%$ efficient under DEA, all that is necessary is that no other branch or linear combination of branches has as much or more of every output and as little or less of every input.

${ }^{7}$ The bank's management argued that this occurred because staff in rural branhces know their customer's habits and communicate better with them.
} 
Their framework relies on the production approach (treating deposits and loans as outputs) because they argue that branches act primarily as producers of depositor services on behalf of the bank, which then invests the funds in loans and other assets. The bank as a whole makes the asset and liability decisions, and branches primarily operate to raise the funds by producing services for depositors. Since branch managers have little control over interest expenses, revenues, or number of transactions required per dollar of deposit, and largely focus on operating expenses, this would argue for using the production approach rather than the intermediation approach for studies of branch efficiency. ${ }^{8}$ The main findings of the Berger, Leusner and Mingo (1997) study are that most branches are considerably smaller than efficient scale but the average cost curves are relatively flat.

\section{Summary}

The previous literature on the banking industry has largely focussed on the role played by scale in determining the efficiency of a bank or a branch. Only two papers have considered other correlates of efficiency but both of these have been at the level of the bank. Delery and Doty (1996) conducted a survey of senior human resource executives in U.S. banks in order to obtain information on the human resource policies used by the banks for their loan officers. ${ }^{9}$ Utilizing a cross-sectional framework that ignored the role of bank fixed effects, they found a positive correlation between the bank's returns on assets and equity and the existence of profit-sharing and employment security for loan officers, controlling for the size and age of the bank. Berger and Mester (1997) utilized data from 6000 U.S.

\footnotetext{
${ }^{8}$ Berger, Leusner and Mingo (1997) suggest that the intermediation approach is more appropriate for studying financial efficiency at the bank level.

${ }^{9}$ Their survey had a response rate of 11 percent, resulting in a sample of 216 banks.
} 
commercial banks to estimate the impact of bank size, organizational form and governance, age of the bank, market characteristics, and state geographic restrictions on competition on three performance measures: total cost divided by gross assets, net income divided by gross assets, and net income divided by equity. They found that most of the variance in measured efficiency remained unexplained and attributed this to unmeasured factors such as differences in managerial ability; they concluded that the sources of the variation in bank efficiency remain a "black box."

Berger and Mester's (1997) findings suggest that managerial ability may play an important role in explaining bank performance. While the ability of the bank's managers at the firm or headquarters level can certainly impact the bank's performance, much of a bank's activities occur at the branch level. In retail banking, customers have idiosyncratic needs and the interactions between these customers and bank employees takes place at the branch level. Hence, the role that the manager might play in motivating employees to successfully fulfill customer needs is best studied at the branch level. No study to date has considered determinants of branch level performance other than branch size.

\section{Getting Inside the "Black Box": Interviews with Branch Managers and Employees}

\section{A. The Work Environment in Bank Branches}

Although the Canadian banking industry is controlled by five major banks, Canada has the highest ratio of full-banking branches to population of all the major industrialized nations (Canadian Bankers Association, 1994). The availability of numerous retail branches coupled with reforms that have allowed banks to expand their product lines has resulted in a very competitive environment in which much attention is paid to opportunities to increase the profitability of retail banking. In addition, 
technological change has resulted in a major organizational redesign in the Canadian banking industry. Many paper-processing tasks typically performed by branch personnel have been moved offsite to "centralized accounting units", thereby radically changing the tasks that branch personnel perform. For example, in the past, tellers simply processed customers' transactions. Today, they are being trained and evaluated on the basis of their ability to sell various financial products or make referrals to the proper sales personnel. In the words of the executive vice-president of human resources at the bank used for this study, "sales is now the name of the game in this industry." 10

The situation facing bank branch employees in this new competitive environment can be represented as a multi-task agency problem with employees deciding how they should allocate their time among different tasks. Employees must decide how to allocate their time to various competing activities, choosing corresponding effort levels for each possible activity. For example, personal bankers must decide how much time to devote to sales (e.g. telephone and personal cold calls, followups with current clients to investigate opportunities for cross-selling products) and non-sales activities (e.g. administrative duties, personal attention to specific clients's needs). Within the range of selling activities, personal bankers must decide whether to emphasize certain products over others (CDs vs. mutual funds for savings and investment decisions, or specific features on different loans).

The branch manager is responsible for motivating his or her employees to make productive choices concerning how they spend their time. Existing theories predict that the HRM environments which managers help create at their branches are likely to influence these critical employee decisions in

\footnotetext{
${ }^{10}$ These changes have also occurred in the U.S. banking industry.
} 
important ways. At the same time, these theories also underscore the complexity of designing a work environment which solves multi-task agency problems. For example, Holmstrom and Milgrom(1994) argue that managers will have to alter an entire set of management practices and procedures simultaneously to achieve the right balance of employee activities.

In order to understand how a branch manager might create a human resource management environment that could impact branch-level performance, I gathered data directly from managers and employees in several branches during the fall of 1995 and the winter of 1996. I asked the bank headquarters to select branches which were perceived as having mediocre HRM environments as well as branches that had model HRM environments. One day was spent in each branch meeting first with the manager and then individually with five or six employees in different positions (e.g. tellers, personal banking officers, customer service representatives, accounting clerks, etc.). These interviews proved to be an invaluable component of the research agenda as they provided me with specific examples of how managers could motivate their employees and influence the branch's performance. In this section, I describe the findings from three of these day-long visits; I selected these three because they provide interesting contrasts of managerial styles and human resource management environments.

\section{B. Branch \#1}

When I visited this branch in January 1996, the manager had been at the branch for almost two years. The manager indicated that although he felt the branch's performance had improved compared to its performance under his predecessor, the branch was not at potential yet. He complained that although he tried to motivate his employees with in-branch contests, the employees were generally apathetic. Many of the employees had been with the branch for more than ten years and there was a 
history of conflict that was interfering with performance.

Although some employees felt the new manager was doing a good job, the interviews with the employees generally confirmed much of what the manager discussed and blamed him for the unsatisfactory work environment and the mediocre performance of the branch. Specifically, they complained about the process of receiving feedback and the reward and recognition system. For example, at least two of the employees complained about the manager's tendency to give negative feedback in front of customers and his encouraging employees to "snitch" about other employees' behaviors. Some of them also complained that the manager did not provide real recognition of employees who performed well. There was a general sense that the employees were not cooperating with each other; for example, one employee recalled that there recently was a long line and only one teller was working, but no one bothered to pitch in.

\section{Branch \#2}

When I visited this branch in January 1996, the manager had been there for only three months. Prior to his joining this branch, he worked in headquarters. Just before the manager's arrival, this branch had been identified as the worst performing branch in its region in terms of the growth of deposits. Upon his arrival, the new manager convened a meeting and asked employees "what do you need to do your job easier or better? The first request was from the head teller for a calculator. Several employees were sharing calculators because previous management said there was no budget to purchase equipment. In addition to providing the calculators, the new manager used his budget to purchase coffee and donuts for the employees. He said that his intent was to keep the staff motivated and happy and, to that end, he set up an open door policy. 
The interviews with the employees painted a picture of very happy employees who were cognizant of the manager's efforts to improve the work environment. They commented extensively about the quality of communications among co-workers and with the manager himself. They felt they were getting much better information from this manager compared to the previous one. In particular, the employees felt they had a much clearer understanding of what the manager expected of them and how their performance was evaluated. All of the employees commented how cooperation among workers had improved and that they had fun working at this branch now. Another area of improvement was the reward and recognition system. One teller discussed how, under the previous manager, she worked through her lunch hour to generate a referral for a mortgage and she received no recognition. The current manager used "time off" as an informal reward and the employees were grateful for this.

\section{Branch \#3}

When I visited this branch in November 1995, the manager had been with the branch for almost two years. Headquarters selected this branch because they felt this manager was a model to which other managers should aspire. The manager described how she held regular staff meetings to teach her employees about new products and how to sell them. She also held contests with small monetary prizes to motivate her employees. Finally, I witnessed that she was truly a hands-on manager. While I was in the branch, she rarely sat in her office; instead, she was at the tellers' platform, either assisting the tellers with questions or actually pitching in as a teller when the lines got long.

The employees in the branch loved their manager. They commented positively about the weekly staff meetings; as one employee put it, "we now know what is going on in all departments." The 
staff meetings were described as having a party atmosphere; one employee told me that the manager used games to teach them about the new products and that sometimes employees danced at the meetings. Communications among employees and between the staff and the manager were described as excellent. "You can talk to her (the manager)...she's one of us," commented one employee. "She's always there for you.. she'll be a teller if there are long lines." The employees also felt that the manager recognized when they did a good job and rewarded them (even if it was only a gift certificate or a halfday off.)

\section{E. Implications of Interview Findings for Empirical Analysis of Branch Performance}

These interviews indicated that although all branch managers are given a formal set of human resource policies by headquarters, they appear to have discretion in their application of these policies and can thereby influence the performance of their branch. This implies that an empirical analysis of the determinants of branch performance needs to include a measure of the human resource management environment at the branch. ${ }^{11}$ Specifically, the interviews indicate that three attributes of that environment are likely to be important factors in explaining branch performance: the nature of communications between co-workers and between the employees and the manager, performance evaluation and feedback, and the extent to which managers provide recognition of their employees' contributions. Employees in branch \#1 were unhappy with the quality of communications in the branch and felt that their contributions were not recognized. Employees in branch \#2 and branch \#3

\footnotetext{
${ }^{11}$ The fact that the human resource management environment varies across branches indicates that a study of the impact of human resource management on performance in the banking industry should not be done at the bank level, but must be done at the branch level. In Part V, the variation in the human resource management environment that exists across the branches in the bank under study is documented in Table 3.
} 
commented favorably about performance feedback, reward and recognition, and the nature of communications at their branches.

In the next section, the specification of the branch performance equation is guided by the previous literature on bank productivity as well as the findings from these interviews.

\section{Specification of a Branch Output Equation and Data Sources}

\section{A. Defining Branch Output}

Beginning in the summer of 1995, I met with numerous branch managers and financial and accounting managers at the bank headquarters in order to identify the best measure of a branch's output. There was general agreement that, in the new sales-oriented environment, branches are evaluated based on their sales of products. In other words, a good branch is one that shows growth of deposits and loans. A branch that experiences high growth rates in deposits and loans will report high spread income, where spread income equals the spread times the value of the deposits and loans as shown on the branch's balance sheet. Spread income is the largest component of a branch's income; the other components are: (1) liability fees such as fees from stop payments, bounced checks, low balances, wire transfers, etc.; (2) asset fees such as fees from loan applications, loan processing, and late payments; (3) transactional fees such as fees for travelers' checks, safe deposit boxes, and ATM transactions; and (4) brokerage commissions. ${ }^{12}$

\footnotetext{
${ }^{12}$ When measuring the performance of an entire bank, a metric known as the efficiency ratio is often used. This is defined as: Non-interest expense/(Interest income + Non-interest income - Interest expense). It is misleading to use the efficiency ratio to compare performance across individual branches of the bank because customers open
} 
In effect, these managers were agreeing with Berger, Leusner and Mingo (1994) and others (Colwell and Davis, 1992) who argue that the production approach is preferrred to the intermediation approach for studies of relative efficiency of branches within a particular bank. According to these managers, their job is to use labor and capital to "produce" deposits and loans, but unlike the specification in the standard production approach, the output of a branch is best measured by its net sales of the deposit and loan products.

Interviews with managers and employees at various branches clarified the process by which branches make sales. Specifically, the observed sales of a branch during time period $t$ is a function of the amount of contact the staff has with customers and the probability that a given interaction with a customer leads to a sale. Customer contact depends on the volume of customer traffic at the branch as well as the number of calls (personal and/or telephone) that personal bankers make to existing and potential customers. The probability of a sale given contact depends on the characteristics of the customer (e.g. wealth, age) as well as the ability of the branch employee to make a sale. The latter in turn is dependent on the employees' experience at the branch (more branch-specific experience leads to stronger relationships with customers) as well as their product knowledge, sales training and motivation. The branch interviews suggest that the branch manager plays a key role in educating staff about products to sell, teaching them how to sell and motivating them to sell through reward and recognition. Hence, sales are a function of the characteristics of the neighborhood in which the branch is located and the individuals who live there, the personal characteristics of the branch employees, and 
the human resource management- related activities (training, motivating, communicating, recognizing, providing feedback) of the branch manager.

To incorporate these ideas, the following branch-level sales equation is specified:

$$
\log \left(\mathrm{SALES}_{\mathrm{it}}\right)=\$_{0}+\$ \mathrm{MKT}_{\mathrm{it}}+\$_{2} \mathrm{~L}_{\mathrm{it}}+\$_{3} \mathrm{HRM}_{\mathrm{it}}+\mathrm{YEAR}+\mathrm{b}_{\mathrm{i}}+\mathrm{m}_{\mathrm{j}}+\mathrm{:}_{\mathrm{t}}
$$

where SALES ${ }_{\mathrm{it}}$ is annual net sales of deposit and loan products in branch $\mathrm{i}$ at time period $\mathrm{t}, \mathrm{MKT}_{\mathrm{it}}$ is a vector of characteristics describing the neighborhood in which the branch is located, $\mathrm{L}_{\mathrm{t}}$ is a vector of employee characteristics, $\mathrm{HRM}_{\mathrm{it}}$ is a vector describing the human resource management environment at the branch and YEAR is a vector of time dummies that measure time-varying effects that are common to branches. Since the dataset provides manager identities, I am able to include two fixed effects in equation (1); the first, $b_{i}$, is a branch fixed effect and the second, $m_{j}$, is a manager fixed effect. This specification allows for the existence of permanent, unmeasured branch characteristics that may affect performance, as well as permanent, unmeasured characteristics of individual managers that may be correlated with performance. The random, unobserved error component is denoted as : ${ }_{\mathrm{t}}$.

\section{B. Data Sources}

\section{Sales}

Although data on the monthly dollar value of deposits and loans were provided to me for each of the branches that the bank operates in the province of Ontario, I was informed that the most accurate data are those that are recorded at the end of the fiscal year, October $31^{\text {st }}$. Hence, a branch's sales are calculated as the percentage growth in deposits and loans from October $31^{\text {st }}$ of the 
previous fiscal year to October $31^{\text {st }}$ of the current fiscal year for the 1995, 1996 and 1997 fiscal years.

\section{Characteristics of the Branch's Market (MKT)}

Branches operate in very different environments which can impact their ability to sell their products. For example, some branches operate in downtown business areas and many of their customers are large businesses. Even within the group of branches that operate in residential areas, there are important differences in terms of age and wealth of customers that can impact performance. Based on my conversations with managers in the bank's marketing department, I have eliminated branches that function as large commercial banking centers. ${ }^{13}$ Branches in rural areas are also excluded, resulting in a sample restricted to branches in metropolitan areas. ${ }^{14}$

For each of the branches in my sample, I was able to obtain detailed information about the branch's location. In particular, the bank defines a branch's "market" by drawing a circle around the branch with a radius of 2.5 kilometers and then gathers data on the population residing within that circle. The following variables were provided for each branch's market: total population, average dwelling value, education, household turnover, unemployment rate, and a "lifestyles" vector that describes the type of people living in the area. There are ten lifestyles categories: affluent, empty nesters, ethnic, low income, middle class, upscale, working class, young singles, young couples, and old/retired. ${ }^{15}$ All of these market characteristics are measured in 1991. In

\footnotetext{
${ }^{13}$ Doukas and Switzer (1991) found that the production technologies of retail and commercial branches are quite distinct.

${ }^{14}$ The metropolitan areas are the cities of Toronto, Ottawa, London, Windsor, Hamilton, Kitchener, Niagara Falls, and Peterborough, and their respective surrounding communities.

${ }^{15}$ This information is provided to the bank by a company called Compusearch.
} 
addition to these variables, I created a dummy variable to indicate if the branch is located in a shopping mall, ${ }^{16}$ and also control for the age of the branch. ${ }^{17}$

\section{Measures of Labor Inputs (L)}

Direct measures of differences in employee characteristics that are likely to be correlated with their productivity could be important determinants of branch performance. Based on my interviews with senior managers in corporate human resources and discussions with branch managers, I have included the following measures. First is the number of full-time and part-time employees at the branch. Second, I have data on the average education and length of service of the branch's employees, as well as the branch manager's tenure at the branch. Third, I was provided with information on the performance ratings of the employees in each branch. Employees at the bank receive performance ratings once a year. Performance scores are A, B, C+, C-, D and E. Only 6.5 percent of branch employees receive the top ratings of $\mathrm{A}$ and $\mathrm{B} ; 25.8$ percent receive $\mathrm{C}+, 47.5$ percent receive $\mathrm{C}-$, and the balance are scored D or E. I calculated the percentage of the branch's employees (excluding the manager) that received a rating of $\mathrm{A}$ or $\mathrm{B}$ and used this in the regressions. Unlike the data describing the branch's market which are only measured at one point in time, the labor input data are measured on a monthly basis beginning in April 1996; prior to that time, they were updated every December. Hence, the characteristics of branch level employees for fiscal year 1995 are a weighted average of the

\footnotetext{
${ }^{16}$ Executives at the bank suggested that these branches were likely to have high sales because of the large concentration of potential customers.

${ }^{17}$ It was impossible to obtain accurate information about the number of competitors in each branch's market area. The bank's data source on number of competitors automatically includes any credit union that is located within the defined market area; hence many branches are shown to have twenty or more competitors.
} 
characteristics reported in December 1994 and December 1995. For fiscal years 1996 and 1997, the variables are more precise because monthly data begin in April 1996.

\section{Human Resource Management Environment}

The interviews described in the previous section suggest that various dimensions of the human resource management environment at a branch are likely to affect branch performance. Specifically, the nature of communications among co-workers and between employees and the manager, the quality of performance evaluation and feedback, and the extent to which managers provide recogniton of their employees' contributions appear to be the important factors. One approach to measuring these dimensions for all the branches in the empirical analysis would be to conduct interviews of employees and managers at each of the branches. But, given the size of the sample, this is infeasible. An alternative approach, which I follow here, is to use data from the employee attitude survey. Employees in each branch complete a survey once every year or every two years (one-third of the branches have completed surveys annually) that measures their assessment of a number of dimensions of the human resource environment at their branch. The bank provided me with the responses to fourteen of the sixty-eight questions on the employee attitude survey; the excluded questions largely concerned attitudes towards pay, employee benefits, job security and physical conditions in the branch. The included questions, listed in Appendix I, focussed on the employee's assessment of the reward and recognition system at the branch, the nature of communication flows between the manager and staff and between co-workers, morale, the level of cooperation, and accessibility of the supervisor. The employee responses are coded on either a five-point or seven-point scale with one being the best. For each branch, I calculated the mean response to each of the fourteen questions. 


\section{Results}

Table 1 reports summary statistics for dependent and independent variables for the 1995, 1996 and 1997 fiscal years. The average annual rate of growth of deposits ranged from 9 to 12 percent while the average annual rate of growth of loans ranged from 5 to 19 percent. Although branches are on average around 34 years old, the average tenure of branch managers is approximately four years. Indeed, among branches observed in both 1995 and 1997, only 57 percent have the same manager in both years. Average tenure (at the branch) of branch employees is about four and one-half years and the average employee (excluding the manager) has around thirteen years of education.

\section{A. OLS Estimates}

Equation (1) was first estimated excluding the branch and manager fixed effects and the results are shown in Tables 2 and $4 .{ }^{18}$ These OLS specifications were done two ways, first excluding the HRM variables (Table 2) and then including them (Table 4).

\section{The Non-HRM Variables}

These variables together explain about 28 percent of the variance across branches in their sales of deposit products and 38 percent of the cross-branch variation in loan sales. Branches that operate in markets with a high rate of household turnover have significantly higher sales of deposits and loans. Other market predictors of the growth in loans is whether the branch operates in a market where the residents are identified as being affluent or upscale. The insignificance of variables like average dwelling

\footnotetext{
${ }^{18}$ In order to be included in the sample, the branch had to have two years of employee survey responses.
} 
value or total population is likely due to the fact that they are stock rather than flow measures and may not be good predictors of sales. For example, sales may be more likely to be related to population growth, rather than the population level. Indeed, many of the market characteristics are correlated with the level of deposit and loan balances at the branch. ${ }^{19}$

Among the branch characteristics, the only variables that are significant are age of the branch and tenure of the employees. Newer branches are observed to have significantly higher rates of growth of deposits. Controlling for age of the branch, branches with junior employees show better performance, perhaps reflecting the ability of younger employees to perform in the new environment that emphasizes sales. An alternative specification of equation (1) is to include the lagged value of deposits or loans in order to better control for the size of the branch. When the lagged value is included, the coefficients on the numbers of full-time and part-time employees are both positive and significant in both equations and the elasticities are larger for the full-time workers. ${ }^{20}$

\section{The HRM Variables}

Table 3, which reports the means and standard deviations of the employee attitude variables, indicates that there is variation across branches in the employee responses to the survey questions. ${ }^{21}$

\footnotetext{
${ }^{19}$ Deposit balances are positively correlated with average dwelling value, total population, percent with post-secondary education, empty nesters, and being located in a shopping mall. Loan balances are highly correlated with average household turnover and being in a shopping mall, and negatively correlated with working-class residents.

${ }^{20}$ The number of employees and lagged balances are positively correlated. Since the lagged value has a negative coefficient, the coefficients on number of employees were reduced when the lagged value was excluded.

${ }^{21}$ It is possible that part of the variation across branches is due to branch-level variation in employee characteristics. Since I include education and tenure of the branch employees in the regressions, I argue that the variation in the responses to the employee attitude questions is capturing the branch effect, unless there is significant cross-branch variation in unmeasured employee characteristics.
} 
Responses that pertain to specific human resource practices have more variability than questions 1 and 2 which are overall ratings of the branch. Each of the employee attitude questions as well as the first principal component of questions 3 through 14 were added separately to the equations in Table 2 and their coefficients and t-values are reported in Table 4. The employee responses are coded on either a five-point or seven-point scale with one being the best. Hence, if a "good" human resource management environment contributes positively to branch performance, the coefficients on the employee attitude variables should have negative signs in the performance equations.

Recall from the discussion of the branch interviews that the three dimensions of the human resource environment that are likely to influence branch performance are: recognition of employee contributions, performance evaluation and feedback, and the quality of communications within the branch. The results in Table 4 confirm that these dimensions do in fact affect branch performance, especially loan sales. The response to the question "When things go well in your job, how often are your contributions recognized?", the third line in Table 4, has a significant effect on the growth rate of deposits. The response to the statement, "I have a clear understanding of how my performance is evaluated", shown in line 4, has a significant effect in the loan equation, as does the response to the question regarding frequency of feedback from supervisor (line 14). Various dimensions of communication within the branch also have significant effects on loan sales: communication from peers (line 8), the ability to communicate upward (line 9), the quality of communications from superiors (line 10), and the overall assessment of communications in the branch (line 11). In addition, the first principal component of the responses to survey questions (3) through (14) has a significant effect on the growth rate of loans. 
The magnitudes of the significant HRM coefficients are rather large. A one standard deviation improvement in the HRM dimensions that are significant in Table 4 corresponds to a 1.2 point increase in the deposit growth rate, or $11 \%$ of the average annual deposit growth rate of 104 and a 1.6 to 2.5 point increase in the loan growth rate, or $14-21 \%$ of the average annual loan growth rate of .117.

\section{B. Fixed Effects Estimates}

The analysis in Table 4 entered each HRM survey variable separately in part because the various attitude responses are closely correlated, presumably because they reflect some underlying aspect of the branch's HRM practices. Bivariate correlations among all pairs of attitude survey questions range from a low of .10 (between the questions about understanding products and the accessibility of the supervisor) to a high of .79 (between the questions about the quality of communications downwards and overall communications). Most correlations are in the .2 to .6 range. Positive correlations among the HRM characteristics could be due either to some other factor that simultaneously produces high levels of all HRM practices, or to complementarities in the use of the different HRM practices, as suggested by Ichniowski, Shaw and Prennushi (1997).

It is possible, therefore, that the results in Table 4 could simply reflect the effect of some omitted branch-specific factor or an omitted manager-specific factor that leads to high levels of sales and more favorable employee attitudes about their branch's HRM environment, rather than a true improvement in performance that is stimulated by better communications and employee recognition and development. In order to distinguish these competing explanations, equation (1) was estimated 
including branch dummy variables and manager dummy variables. ${ }^{22}$

The results of estimating the fixed effects model are shown in Table 5. The main finding from Table 5 is, that controlling for unobserved branch characteristics and unobserved manager characteristics, some dimensions of the human resource management environment still have significant effects on branch-level performance. The dimensions of the human resource management environment that had been identified through the branch visits as likely to have an impact on branch performance, i.e. the performance evaluation and feedback system, and the quality of communications between the manager and staff, and between co-workers, remain significant in both the deposit and loan regressions (communicate upward and frequency of feedback for deposits, and understand performance evaluation, communications from peers, communications from superiors and frequency of feedback in the case of loans). The magnitudes of these significant effects are at least as large as the OLS results. A one-standard deviation improvement in the HRM dimensions that are significant in the deposit equation produces an increase in deposits that equals 16-26\% of the average annual deposit growth rate. In the case of loans, the significant factors produce an increase that equals $20-26 \%$ of the average annual growth rate.

The fact that the HRM variables remain significant even when branch dummy variables and manager dummy variables are included indicates that the effects of the HRM variables that were observed in the OLS specification were not due to unobserved branch characteristics or unobserved personality characteristics of particular managers. Rather, the evidence presented here indicates that

\footnotetext{
${ }^{22}$ If the branch has the same manager in both time periods, then a dummy variable can not be included for this manager, because the branch and manager fixed effects are indistinguishable. In the case of a branch with two different managers in the two time periods, a branch dummy and a dummy for one of the managers can be included..
} 
branch-level performance can be impacted by specific actions undertaken by managers. ${ }^{23}$

Recall that we have argued that the situation facing bank branch employees can best be thought of as a multi-task agency model with employees deciding how they should allocate their time among various competing tasks and the manager trying to motivate the employees to make productive choices regarding time allocation. The findings in Table 5, where the human resource variables are more consistently significant in the loan equations, suggest that employee activities that lead to new loan business are more responsive to the human resource management activities undertaken by the manager than are the employee activities that are correlated with the sales of deposit products.

Another way of gauging the importance of the manager's actions is to consider how the coefficients on the manager dummy variables are affected by the inclusion of the survey responses. When equation (1) was estimated without the employee survey responses, five manager dummy variables were significant in the deposit equation and eight manager dummy variables were significant in the loan equation. These coefficients are shown in the first column of Table 6. In order to understand which activities undertaken by the manager could account for these significant manager effects, the remaining columns in Table 6 show how the manager coefficients were affected by the inclusion of the six employee attitude questions that were significant in Table 5. The coefficient for Manager \#78 in the deposit equation becomes insignificant when the employee responses to the question on the quality of upward communications is added to the equation, indicating that an important part of this manager's

\footnotetext{
${ }^{23}$ It should be noted that the approach used here can not explain why there is a change in the human resource management environment at a branch. The time series is not long enough to consider whether branches with, for example, low growth rates of deposits and loans experience an improvement in their HRM environments. The results in Table 5 do, however, rule out the impact of an omitted branch-specific or manager-specific factor.
} 
success was due to the employees feeling that they could easily communicate with the manager. This manager's success also appears to be related to the frequency of feedback he/she gives to the employees. Another example is that of Manager \#14 who had a positive effect on loan sales which can be at least partly explained by his/her communications down to the employees and the frequency of feedback given to the employees. Manager \#80's success also appears to be related to the quality of communications from the manager to his/her employees.

\section{Post-1995 Performance of Visited Branches}

The importance of estimating the relationship between human resource management and performance in a fixed effects framework is highlighted by an examination of the post-1995 performance of the three branches that I visited in 1995. Recall from Part IV that, in January 1996, Branch \#2 had a relatively new manager who was making significant changes in the HRM environment at the branch in order to improve the branch's lackluster performance. The data for this branch show an improvement in loan growth performance (a 16\% increase in sales from fiscal 1995 to fiscal 1996) along with a significant improvement in employees' perceptions about the quality of communications at the branch comparing the 1995 and 1996 employee surveys. By contrast, Branch \#3 had excellent loan growth performance in 1995 and the employees were very satisfied with the quality of communications at the branch that year. In fiscal 1997, however, the employees were much less satisfied with the quality of communications at the branch even though the same manager was present, and the data also show that the loan growth rate was down significantly for this branch. Branch \#1, which had not been performing well in 1995, experienced a significant fall-off in loan growth performance between 1995 and 1997 along with a further deterioration of communications at the 
branch that occurred after the arrival of a new manager in July $1996{ }^{24}$

\section{Conclusions}

Empirical research on the relationship between human resource management practices and establishment performance has focussed on blue collar workers in manufacturing despite the fact that most employees work in white collar occupations and service sector industries. This paper extends the analysis of this relationship to the service sector by examining the retail branch operations of a large Canadian bank. A unique dataset collected through site visits was used to estimate the determinants of branch-level performance and specifically to consider if the human resource management environment at a branch is one of those determinants. Previous studies of branch performance have largely focussed on the role played by scale in determining the efficiency of a bank branch despite the fact that most of the variance in measured efficiency remained unexplained in those studies.

Interviews with managers and employees were used to guide the specification of the branchlevel production function and the empirical definition of the branch's human resource management environment. The econometric analysis showed that, controlling for the characteristics of the market in which the branch is located and the characteristics of the branch employees, as well as unobserved branch-specific and manager-specific characteristics, the human resource management environment at

\footnotetext{
${ }^{24}$ These findings indicate that in the financial services sector changes in human resource management practices impact performance fairly quickly. Some studies of the manufacturing sector (e.g. Kato and Morishima, 1999 and Helper et.al.,1999) have found that the introduction of employee information sharing programs or employee involvement programs impact performance with a seven year (the Kato study) or two to three year time lag (the Helper study). The more immediate gains observed here may be due to the fact that the change in the human resource management practice occurs at the branch level and is designed by the manager himself and, unlike the situation for the manufacturing companies, is not a corporate decision that then needs to be implemented at the shop level.
} 
the branch, as measured by the quality of the performance feedback system and the quality of communications between the manager and the staff, had significant effects on the branch's performance, especially its sales of loans. A one standard deviation improvement in those attributes of the human resource management environment that had significant effects corresponded to an increase in the growth of deposits and loans that was equivalent to 16-26 percent of the average annual growth rates.

An important finding from this study is that, even though all managers in this bank are given a formal set of human resource policies, they appear to have considerable discretion in their application. Evidence from the branch visits showed that some managers took actions that created real differences in the extent to which recognition of employee contributions, performance feedback and information sharing were characteristic of their branches, and the econometric analysis demonstrated that these HRM practices significantly impacted performance. The fact that the HRM variables remained significant even when manager dummy variables were included in the regressions indicates that the results are not due to unobserved personality characteristics of particular managers. Rather, the evidence in this paper supports the notion that branch-level performance in the banking industry can be improved if managers undertake specific human resource management-related actions. 


\section{Bibliography}

Aly, Hassan Y., Richard Grabowski, Carl Pasurka and Nanda Rangan, "Technical, Scale, and Allocative Efficiencies in U.S. Banking: An Empirical Investigation," Review of Economics and Statistics 72 (1990) 211-218.

Baker, George, Robert Gibbons, and Kevin Murphy, "Subjective Performance Measures in Optimal Incentive Contracts, Quarterly Journal of Economics, Vol. CIX, 1994, pp. 1123-1156.

Benston, George J., Gerald A. Hanweck and David B. Humphrey, "Scale Economies in Banking: A Restructuring and Reassessment," Journal of Money, Credit and Banking 14 (1982) 435-456.

Berger, Allen N. and David B. Humphrey, "Measurement and Efficiency Issues in Commercial Banking," in Zvi Griliches, ed., Output Measurement in the Service Sector, NBER Studies in Income and Wealth Volume 56, University of Chicago Press, 1992.

Berger, Allen N., John H. Leusner and John J. Mingo, “The Efficiency of Bank Branches,” Board of Governors of the Federal Reserve System Working Paper, August 1994.

Berger, Allen N. and Loretta J. Mester, "Inside the Black Box: What Explains Differences in the Efficiencies of Financial Institutions?' Wharton Financial Institutions Center, Working Paper 97-04, January 1997.

Canadian Bankers Association, “Bank Facts 1994,” mimeo., Toronto, 1994.

Colwell, R.J. and E.P. Davis, "Output and Productivity in Banking," $\underline{\text { Scandinavian Journal of }}$ Economics 94, Supplement, 1992, pp. 111-129.

Delery, John E. and D. Harold Doty, "Modes of Theorizing in Strategic Human Resource Management: Tests of Universalistic, Contingency, and Configurational Performance Predictions," Academy of Management Journal 39 (1996): 802-835.

Doukas, John and Lorne N. Switzer, "Economies of Scale and Scope in Canadian Branch Banking," Journal of International Financial Markets, Institutions and Money 12 (1991), 61-84.

Elyasiani, Elyas and Seyed Mehdian, "Efficiency in the Commercial Banking Industry, A Production Frontier Approach,” Applied Economics 22 (1990a) 539-551. 
Change: The Case of Large U.S. Commercial Banks,"

Journal of Financial Services Research 4 (1990b) 157-168.

Ferrier, Gary D. and C.A.Knox Lovell, "Measuring Cost Efficiency in Banking: Econometric and Linear Programming Evidence," Journal of Econometrics 46 (1990) 229-245.

Griliches, Zvi,'Introduction" in Zvi Griliches, ed., Output Measurement in the Service Sector, NBER Studies in Income and Wealth Volume 56, University of Chicago Press, 1992.

Hancock, Diana, "A Model of the Financial Firm with Imperfect Asset and Deposit Elasticities," Journal of Banking and Finance 10 (1986) 37-54.

Helper, Susan, David Levine and Elliot Bendoly, "Employee Involvement and Pay at U.S. and Canadian Auto Suppliers," unpublished manuscript, 1999.

Holmstrom, Bengt and Paul Milgrom, "The Firm as an Incentive System," American Economic Review 84, 1994, pp. 972-991.

Ichniowski, Casey, Kathryn Shaw and Giovanna Prennushi, "The Effects of Human Resource Management Practices on Productivity: A Study of Steel Finishing Lines," American Economic Review 87 (1997): 291-313.

Ichniowski, Casey, Thomas Kochan, David Levine, Craig Olson and George Strauss, "What Works at Work: Overview and Assessment," Industrial Relations 35 (1996): 299-333.

Kato, Takao and Motohiro Morishima, "The Productivity Effects of Participatory Employment Practices: Evidence from New Japanese Panel Data," unpublished manuscript, May 1999 (Revised version of paper presented at NBER Summer Institute, 1998).

Lazear, Edward, "Labor Economics and the Psychology of Organizations," Journal of Economic Perspectives 8, 1991, pp.89-110. ,Personnel Economics, (Cambridge, MA: MIT Press), 1995. , "Personnel Economics: Past Lessons and Future Directions," Journal of Labor Economics 17, 1999, pp. 199-236.

Milgrom, Paul and John Roberts, "The Economics of Modern Manufacturing," American Economic Review 80 (1990): 511-28. 
, "Complementarities and Fit: Strategy, Structure and Organizational Change in Manufacturing," Journal of Accounting and Economics 19 (1995): 179-208.

Murphy, N.B. and Y.E. Orgler, "Cost Analysis for Branching Systems: Methodology, Test Results, and

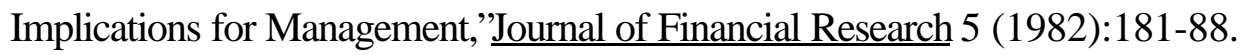

Parkan, Celik, "Measuring the Efficiency of Service Operations: An Application to Bank Branches," Engineering Costs and Production Economics 12 (1987) 237-242.

Prasad, Baba and Patrick T. Harker, "Examining the Contribution of Information Technology Toward Productivity and Profitability in U.S. Retail Banking," Wharton Financial Institutions Center, Working Paper 97-09, March 1997.

Schaffnit, Claire, Dan Rosen and Joseph C. Paradi, "Best Practice Analysis of Bank Branches: An Application of DEA in a Large Canadian Bank," European Journal of Operational Research 98 (1997), 269-289.

Sherman, H. David and Franklin Gold, "Bank Branch Operating Efficiency: Evaluation with Data Envelopment Analysis,” Journal of Banking and Finance 9 (1985), 297-311.

Zardkoohi, Asghar and James Kolari, "Branch Office Economies of Scale and Scope: Evidence from Savings Banks in Finland," Journal of Banking and Finance 18 (1994), 421-432. 


\section{Table 1 \\ Summary Statistics}

Mean $\underline{\text { Std Dev }}$

Annual Growth Rate of Deposits

Annual Growth Rate of Loans

Average Dwelling Value

Total Population

Proportion with Post-Second

Education

HH Turnover Rate

Affluent

Empty Nesters

Ethnic

Low

Middle

Upscale

Work

Located in Mall

Age(in years)

Manager's Tenure in Branch

Number of Full Time Employees

Number of Part Time Employees

Average Education (Employees)

Average Tenure (Employees)

Share of Employees with Top

Ratings
Fiscal Year 95

Fiscal Year 96

$\underline{\text { Mean }} \quad \underline{\text { Std Dev }}$

183155

$$
.50
$$

.10

.06

.03

.13

.06

.06

.17

.28

.09

.08

34.49

4.03

9.87

8.36

12.71

4.57

.05

.02

.18

.34

.24

.24

.38

.45

.29

.27

25.09

3.56

5.26

5.89

.56

2.31

.06
.10

.10

46409

.49

.11

.09

58133

34886

.10

.06

.03

.14

.10

0

.19

.27

.11

.16

35.97

4.28

11.35

9.86

12.83

4.44

.05
.02

.18

.35

.30

0

.40

.45

.32

.37

24.79

3.72

5.70

5.64

.55

2.20

.07
Fiscal Year 97

Mean

.09

.05

.10

.11

64117

34396

.10

.51

.06

.02

.16

.34

.25

.24

.38

.46

.29

.11

.31

36.64

25.16

4.34

3.61

10.36

4.95

8.55

5.10

13.01

.54

4.42

2.13

.05

.07 
Table 2

Determinants of Branch-Level Productivity (OLS)

1995, 1996, and 1997 Fiscal Years

(all regressions include year and city dummies)

$\begin{array}{lcccc}\text { INDEPENDENT VARIABLES } & \mathrm{b} & \begin{array}{c}\text { Growth Rate } \\ \text { of Deposits }\end{array} & \mathrm{t} & \begin{array}{c}\text { Growth Rate } \\ \text { of Loans }\end{array} \\ & \mathrm{b} & \mathrm{t} & \mathrm{b} & \mathrm{t}\end{array}$

Market Characteristics

\begin{tabular}{|c|c|c|c|c|}
\hline Avg Dwl Value & .014 & $(.67)$ & -.014 & $(-.59)$ \\
\hline Total Population & .040 & $(1.28)$ & .026 & $(.75)$ \\
\hline$\% 13+$ Education & -.001 & $(-1.12)$ & -.001 & $(-.67)$ \\
\hline HH Turnover & .009 & $(2.05)$ & .013 & $(2.79)$ \\
\hline Affluent & .007 & $(.15)$ & .090 & $(1.86)$ \\
\hline Empty Nesters & -.033 & $(-1.26)$ & .001 & $(.02)$ \\
\hline Ethnic & -.047 & $(-1.39)$ & .013 & $(.35)$ \\
\hline Low & -.012 & $(-.37)$ & .060 & $(1.61)$ \\
\hline Middle & -.013 & $(-.47)$ & .042 & $(1.41)$ \\
\hline Upscale & .022 & $(.87)$ & .062 & $(2.21)$ \\
\hline Working & -.008 & $(-.28)$ & .043 & $(1.36)$ \\
\hline \multicolumn{5}{|l|}{ Branch Characteristics } \\
\hline Located in Mall & -.002 & $(-.08)$ & -.025 & $(-1.01)$ \\
\hline Age & -.020 & $(-2.04)$ & -.014 & $(-.68)$ \\
\hline Manager Tenure & -.0002 & $(-.98)$ & -.00014 & $(-.45)$ \\
\hline Log (\#Full Time Employees) & -.005 & $(-.22)$ & -.056 & $(-2.07)$ \\
\hline Log (\#Part Time Employees) & .012 & $(.82)$ & .024 & $(1.49)$ \\
\hline Avg Education of Employees & .002 & $(.14)$ & -.007 & $(-.57)$ \\
\hline Avg Tenure of Employees & -.001 & $(-3.03)$ & -.001 & $(-2.72)$ \\
\hline $\begin{array}{l}\% \text { Employees with } \\
\text { Top Rating }\end{array}$ & .0003 & $(.28)$ & -.0003 & $(-.24)$ \\
\hline $\mathrm{N}$ & 359 & & 359 & \\
\hline $\mathrm{R}^{2}$ & .275 & & .378 & \\
\hline
\end{tabular}


Table 3

Means and Standard Deviations of Employee Survey Questions*

\begin{tabular}{lcccccc} 
& \multicolumn{2}{c}{ Fiscal Year 95} & \multicolumn{2}{c}{ Fiscal Year 96} & \multicolumn{2}{c}{ Fiscal Year 97} \\
& $\underline{\text { Mean }}$ & $\underline{\text { Std Dev }}$ & $\underline{\text { Mean }}$ & $\underline{\text { Std Dev }}$ & $\underline{\text { Mean }}$ & $\underline{\text { Std Dev }}$ \\
1. Overall Rating & 2.52 & .29 & 2.44 & .25 & 2.42 & .30 \\
2. Rating Compared to Last Year & 2.04 & .28 & 1.89 & .26 & 1.97 & .24 \\
3. Contributions are Recognized & 2.73 & .45 & 2.60 & .40 & 2.16 & .44 \\
4. Understand Perf. Evaluation & 2.22 & .33 & 2.12 & .26 & 1.95 & .30 \\
5. Express Views at Meetings & 2.29 & .43 & 2.26 & .43 & 2.00 & .35 \\
6. Understand Products & 1.85 & .25 & 1.84 & .20 & 2.38 & .57 \\
7. Morale in Branch & 2.76 & .46 & 2.82 & .49 & 2.28 & .48 \\
8. Communications from Peers & 2.95 & .64 & 2.79 & .53 & 2.33 & .44 \\
9. Communicate Upward & 2.93 & .49 & 2.91 & .47 & 2.77 & .49 \\
10. Communications from Superiors & 3.14 & .64 & 3.09 & .57 & 2.21 & .57 \\
11. Overall Communications & 3.10 & .60 & 3.03 & .46 & 2.50 & .59 \\
12. Cooperation in Branch & 3.08 & .50 & 2.92 & .49 & 2.55 & .50 \\
13. Supervisor Accessible & 2.39 & .55 & 2.35 & .51 & 2.12 & .45 \\
14. Frequency of Feedback & 2.01 & .37 & 2.12 & .37 & 2.58 & .46
\end{tabular}

\footnotetext{
* Responses are scored 1-5 for questions 1-7 and 12-14, and are scored 1-7 for questions 8-11. The highest score is 1 . See Appendix I for actual wording of questions.
} 
Table 4

Effects of Employee Attitudes on Branch-Level Productivity (OLS) (Attitudes are Scored 1-5 or 1-7 and 1 is the best score)*

\begin{tabular}{|c|c|c|c|c|}
\hline & \multicolumn{2}{|c|}{$\begin{array}{l}\text { Growth Rate } \\
\text { of Deposits }\end{array}$} & \multicolumn{2}{|c|}{$\begin{array}{c}\text { Growth Rate } \\
\text { of Loans }\end{array}$} \\
\hline & $\mathrm{b}$ & $\mathrm{t}$ & $\mathrm{b}$ & $\mathrm{t}$ \\
\hline Overall Rating of Bank & .005 & $(.21)$ & -.044 & $(-1.79)$ \\
\hline Rating Compared to Last Year & .004 & $(.18)$ & -.052 & $(-1.92)$ \\
\hline Contributions Are Recognized & -.024 & $(-1.68)$ & -.025 & $(-1.56)$ \\
\hline Understand Perf. Evaluation & -.006 & $(-.30)$ & -.067 & $(-2.89)$ \\
\hline Express Views at Meetings & -.006 & $(-.36)$ & -.045 & $(-2.48)$ \\
\hline Understand Products & -.010 & $(-.65)$ & -.038 & $(-2.23)$ \\
\hline Morale in Branch & -.011 & $(-.76)$ & -.038 & $(-2.44)$ \\
\hline Communications from Peers & -.008 & $(-.67)$ & -.024 & $(-1.80)$ \\
\hline Communicate Upward & -.017 & $(-1.26)$ & -.033 & $(-2.26)$ \\
\hline Communications from Superiors & -.008 & $(-.70)$ & -.032 & $(-2.71)$ \\
\hline Overall Communications & -.004 & $(-.38)$ & -.039 & $(-3.02)$ \\
\hline Cooperation in Branch & -.007 & $(-.54)$ & -.008 & $(-.53)$ \\
\hline Supervisor Accessible & -.023 & $(-1.74)$ & -.009 & $(-.58)$ \\
\hline Frequency of Feedback & -.023 & $(-1.52)$ & -.044 & $(-2.60)$ \\
\hline $1^{\text {st }}$ Principal Component & -.004 & $(-1.10)$ & -.010 & $(-2.85)$ \\
\hline $\mathrm{N}$ & 359 & & 359 & \\
\hline
\end{tabular}

\footnotetext{
* Line 15 is the first principal component of rows 3-14. In rows 1-14, the questions are entered individually. These are coefficients and t-values from complete regressions as specified in Table 2.
} 
Table 5

Effects of Employee Attitudes on Branch-Level Productivity

Controls for Branch Fixed Effects and Manager Fixed Effects

(Attitudes are scored 1-5 or 1-7 and 1 is the best score)*

\begin{tabular}{lccccccc} 
& \multicolumn{3}{c}{$\begin{array}{c}\text { Growth Rate } \\
\text { of Deposits }\end{array}$} & & \multicolumn{3}{c}{$\begin{array}{c}\text { Growth Rate } \\
\text { of Loans }\end{array}$} \\
& $\mathrm{b}$ & $\mathrm{t}$ & $\mathrm{R}^{2}$ & $\mathrm{~b}$ & $\mathrm{t}$ & $\mathrm{R}^{2}$ \\
Overall Rating of Bank & -.005 & $(-.12)$ & .417 & -.032 & $(-.76)$ & .605 \\
Rating Compared to Last Year & .026 & $(.62)$ & .419 & -.002 & $(-.04)$ & .603 \\
Contributions Are Recognized & -.033 & $(-1.25)$ & .425 & -.023 & $(-.88)$ & .605 \\
Understand Perf. Evaluation & -.010 & $(-.25)$ & .417 & -.078 & $(-2.03)$ & .617 \\
Express Views at Meetings & -.011 & $(-.36)$ & .417 & -.020 & $(-.67)$ & .604 \\
Understand Products & .027 & $(.93)$ & .421 & -.028 & $(-.97)$ & .606 \\
Morale in Branch & -.025 & $(-1.03)$ & .422 & -.024 & $(-.99)$ & .606 \\
Communications from Peers & -.023 & $(-1.01)$ & .422 & -.037 & $(-1.68)$ & .613 \\
Communicate Upward & -.055 & $(-2.31)$ & .444 & -.013 & $(-.53)$ & .604 \\
Communications from Superiors & -.022 & $(-1.12)$ & .423 & -.040 & $(-2.07)$ & .618 \\
Overall Communications & -.011 & $(-.46)$ & .418 & -.037 & $(-1.59)$ & .612 \\
Cooperation in Branch & -.014 & $(-.64)$ & .419 & .006 & $(.27)$ & .603 \\
Supervisor Accessible & -.026 & $(-1.05)$ & .422 & .026 & $(1.07)$ & .607 \\
Frequency of Feedback & -.049 & $(-1.75)$ & .433 & -.055 & $(-1.99)$ & .617 \\
$1^{\text {st }}$ Principal Component & -.008 & $(-1.41)$ & .427 & -.008 & $(-1.35)$ & .609 \\
$\mathrm{~N}$ & 359 & & & 359 & &
\end{tabular}

* The questions are entered individually. These are coefficients and t-values from regressions that also include time-varying branch characteristics. When the survey variables are excluded, the R-squared in the deposit equation is .417 and in the loan equation is .603 . 
Table 6

Significant Manager Effects and The Impact of Controlling for Employee Attitudes

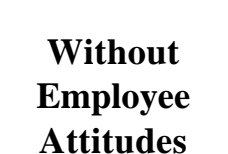

A. DEPOSITS

Mgr 29

Mgr 69

Mgr 72

Mgr 78

Mgr 87

\section{B. LOANS}

Mgr 1

Mgr 14

Mgr 16

Mgr 45

Mgr 73

Mgr 80

Mgr 87

Mgr 107

$$
\begin{gathered}
.81 \\
(3.39)
\end{gathered}
$$$$
.35
$$$$
\text { (2.03) }
$$$$
-.39
$$$$
(-1.68)
$$$$
\begin{array}{r}
.27 \\
1.86)
\end{array}
$$$$
\begin{gathered}
(1.86) \\
.31
\end{gathered}
$$

(1.81)

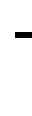

$\begin{array}{cc}\begin{array}{c}\text { Understand Perf. } \\ \text { Evaluation }\end{array} & \begin{array}{c}\text { Communication } \\ \text { from Peers }\end{array} \\ \end{array}$

With Responses to Questions On: Upward
Communication

from Superior Communication
Frequency of

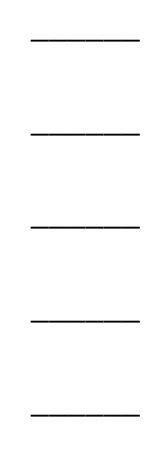

.33

(1.88)

.26

(1.61)

$-.28$

$(-1.69)$

$-.37$

$(-2.15)$

.64

(3.86)

.26
$(1.45)$

.33

(1.93)

.33

(2.03)

$$
\begin{gathered}
.82 \\
(3.48) \\
.38 \\
(2.23) \\
-.49 \\
(-2.13) \\
.21 \\
(1.44) \\
.32 \\
(1.86)
\end{gathered}
$$
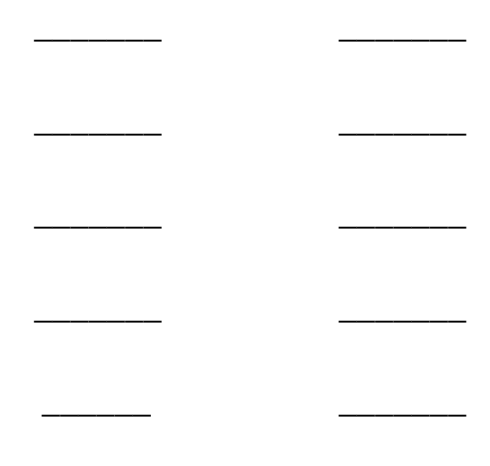

.82

$3.48)$

.39

(2.28)

$-.45$

$(-1.96)$

.24

(1.62)

.29

(1.67)

.34

(1.91)

.33
$(1.85)$

.29

(1.64)

.22

(1.33)

$-.27$

(-1.59)

$-.39$

$(-2.28)$

.62

(3.76)

.25
$(1.42)$

.31

(1.84)

.33

(2.03)

$$
\begin{gathered}
.22 \\
(1.33) \\
-.31 \\
(-1.86) \\
-.38 \\
(-2.21)
\end{gathered}
$$$$
.61
$$

(3.69)

.25
$(1.38)$

.34

(1.99)

(2.11)
.21

(1.23)

$-.32$

$(-1.94)$

$-.36$

$(-2.14)$

.61

(3.70)

.30

(1.69)

.30

(1.75)

.36

(2.21) 


\section{Appendix I}

\section{Questions Used from Employee Attitude Survey*}

1. Overall, how would you rate the bank as a place to work?

2. How would you rate the bank as a place to work compared with a year ago?

3. When things go well in your job, how often are your contributions recognized?

4. I have a clear understanding of how my performance is evaluated.

5. I feel comfortable expressing my views/suggestions at staff/branch/departmental meetings.

6. I have a good understanding of the bank's products and services that I am expected to promote/sell.

7. Morale is high in my department.

8. Communications to you from others at the same organization tend to be: extremely good....extremely poor (seven-point scale).

9. Opportunities to communicate upward tend to be: extremely good...extremely poor (seven-point scale).

10. Communications downward to you tend to be: extremely good...extremely poor (seven-point scale).

11. Everything considered, communications tend to be: extremely good...extremely poor (seven-point scale).

12. How would you rate your branch/department on cooperation among employees?

13. How would you rate your immediate supervisor on being easy to see when you have a problem or complaint?

14. How would you rate your immediate supervisor on letting you know how you are doing your job on a regular basis?

* With the exception of questions 8,9,10 and 11, responses are on a five-point scale with one being the best. Questions $8,9,10$ and 11 are coded on a seven-point scale with one being the best. 